\title{
平成16年度粉体基礎現象研究グループ会活動報告
}

\section{Annual Report of Working Group on Fundamental Phenomena in Powder Process, 2004}

粉体基礎現象グループ会は，特に，大学・企業等の研 究機関において粉体工学のこれからの展開を考えなけれ ばない立場にある中堅研究者を対象として，それそれが 持つ情報や意見を交換し，参加者各自の研究遂行の参考 とするだけでなく，全員で粉体工学の新しい体系化や新 しい展開を模索する場として活動している。現在まで, 年 2 回の講演会開催を中心として活動しており, その講 演会では何か「まとまった話を聞いて勉強してみたい」 ようなキーワードを毎回設定して, 企画性のある講演会 を実施している。

平成16年度の第 1 回講演会は，11月11日，12日に幕張 メッセ国際会議場で開催された粉体工学会秋期研究発表 会のシンポジウムとして開催した。本シンポジウムでは テーマを「粉体操作中での基礎現象」とし，基礎現象を 学際的・包括的に検討する会として活動している当グ ループ会と「粉体操作に伴う諸現象に関する勉強会（通 称: 若手勉強会)」とのジョイントで，当グループ会の世 話人 2 名,「粉体操作に伴う諸現象に関する勉強会」より 田之上健一郎氏 (山口大学), 押谷 潤氏 (岡山大学) の 計 4 名が共同でオーガナイズした。

このシンポジウムでも，やはり，「まとまった話を聞 いて勉強してみたい」ようなキーワードを設定し，日頃 粉体工学会では発表されない研究者の基調講演を中心に 構成した。キーワードを「粒子設計」「粒子凝集・分 散」「流体透過」とし， 3 件の基調講演をお願いした。 また，同じキーワードで研究発表を公募したところ， 3 件の応募があった。このシンポジウムでのプログラムを 以下に示す。

\section{【プログラム】}

基調講演 1 「粉 - 液接触瞬間を制御する分散方式の開発 とその効果」（特殊機化工業）麻 彪

基調講演 2 「高分子微粉体における機能発現と最適化」 （岡山大・環境理工）吉澤 秀和 基調講演 3 「アパタイトの粒子設計・表面設計」

（島根大・総合理工）田中 秀和 研究発表「振動分光法による微視的な粒子の混合分散 状態の評価」

(大阪ライフサイエンスラボ）○寺下敬次郎
(エス・ティ・ジャパン) 古川 剛志, 落合 周吉 研究報告「粉体接触解析」岡本 廣祐 研究報告「X線小角散乱法を用いたナノ粒子の粒径分 布解析」

（リガク）○佐々木明登, 伊藤 義泰 平成16年度第 2 回グループ会は「粉体・粒子系工学と 環境・生物プロセス工学との交わり」と題して, 創価大 学工学部（八王子）にて開催した。本講演会では, 生ゴ ミ処理におけるコンポスト化反応器・メタン発酵プロセ スなど、いわゆる環境・生物プロセス工学の中へ，粉 体・粒子系工学的な視点からどのように切り込むことが できるのか, どのような課題が見い出されるのか等を議 論する場として，以下の講演および見学会を実施した。

【プログラム】

講演 1 「固液二相循環法による生ゴミ処理」

（(株)シーウェル）長尾宣夫

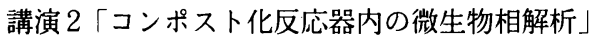

（創価大学工学部）黒沢則夫 講演 $3 「 x タ ン$ 発酵プロセスの微粒子工学的アプローチ」 (大阪府立大学) 野村俊之

見学会「創価大学環境技術開発共同研究センター」

粉体を取り扱う分野は工学だけでなく薬学や化学, 農 学など多岐にわたっている。このため, 粉体工学の新し い体系化や新しい領域への展開を模索するためには，現 在, 異分野亡される領域間で情報および意見の交換をす ることが必要であると考えている。そこで，これまで， いろいろな分野において異なった目的で研究を行ってい る研究者を招き，情報と意見交換の中から，操作の目的 によって一見異なった側面を見せる種々の粉体現象を支 配する普遍的な素過程を検討する場として, 活動を行っ ている。

本会の講演会の予定はグループ会ホームページ (http :// kona.t.soka.ac.jp/G_fundamental/default. html）に逐次掲載をしております。本会の活動にご興味 のある方は当然ながら，個別の講演会だけにでもご興味 のある方はぜひともご参加ください。

(岡山大学 後藤 邦彰) 